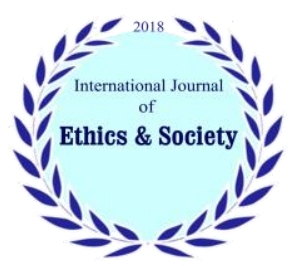

International Journal of Ethics \& Society (IJES)

Journal homepage: $\underline{\text { www.ijethics.com }}$

Vol. 3, No. 2 (2021)

(Original article)

\title{
Identifying the Effective Factors on Ethical and Social Education of Students
}

\author{
Naser Sepehrí, Mostafa Niknami ${ }^{b^{*}}$, Nadergholi Ghorchian ${ }^{c}$, Ali Taghipourzahif \\ a) Ph.D. Student of Educational Management, Faculty of Management and Economics, Science and Research Branch, \\ Islamic Arad University, Tehran, Iran. \\ b) Dept. of Educational Management, Faculty of Educational Sciences and Psychology, Allameh Tabatabaei University, \\ Tehran, Iran. \\ c) Dept. of Educational Management, Faculty of Management and Economics, Science and Research Branch, Islamic \\ Arad University, Tebran, Iran.
}

\begin{abstract}
Background: Regarded to the rapid and increasing growth of science and technology, yet one of the main challenges of today's human beings is the issue of ethical and social education. As a result, this study was conducted with the aim of identifying the effective factors on ethical and social education of students with emphasis on the fundamental reform document of education.

Method: This study in terms of purpose was applied and in terms of implementation was qualitative from type of content analysis. The research community was documents and resources and experts of education. The research sample was documents and resources related to ethical and social education and 22 experts of education who according to the principle of theoretical saturation were selected by purposive sampling method. Data were collected by take noting and semi-structured interview methods and were analyzed by content analysis method in three stages of open, axial and selective coding through MAXQDA software.

Results: The findings showed that ethical and social education of students with emphasis on the fundamental reform document of education had 35 sub-factors and 6 main factors (factors of individual, family, local community, school, media and information technologies and changes in the world community). Finally, according to the sub and main factors, was designed the conceptual pattern of effective factors on ethical and social education of students with emphasis on the fundamental reform document of education.

Conclusion: Based on the pattern of ethical and social education of present research, education specialists and planners can design and implement programs to improve the ethical and social education of students.
\end{abstract}

Keywords: Ethical education, Social education, Students, Fundamental reform document, Education

*Corresponding Author: Email: dr.m_nilknami@yahoo.com

Received: 27 Feb 2021

Accepted: 22 May 2021

52

Available at: www.ijethics.com 
Niknami M. et al.

International Journal of Ethics \& Society (IJES), (2021) Vol. 3, No. 2

\section{Introduction}

Today, the process of globalization has caused people beyond the borders of a country to interact and exchange ideas, which has fundamentally changed the systems of education (1). Education is one of the sublime infrastructures of the whole society of the country and a serious tool for promoting decent human capital in different areas of the country. The education system of the country has not been able to function properly, so change in it is an inevitable necessity. So far, various policies and strategies have been used to change this system, which have not been very successful. Thus, the fundamental change in education based on the philosophy of Islamic education is designed to achieve goals such as a deep belief in Islam and high ideas and values and to achieve the vision of 1404 (2). In our country, many people, despite knowing and believing in ethical values such as fairness, loyalty, trustworthiness and honesty, commit immoral acts. Since education is the flagship of ethical and religious education of new generations, so this issue indicates the inefficiency of this system for proper moral education (3). Today, human beings have achieved remarkable success in various fields, especially in the field of science and technology, but in the field of ethics, moral and social education, they face many challenges and problems (4). One of the most important social issues of man is the issue of moral development, which was studied by theorists and researchers in sociology and psychology. Social and moral development are related to each other, and from this perspective, along with cognitive and moral development, one gradually finds an image of oneself among others and in relation to others, which shapes children's social and ethical communication with other people (5).

In recent decades, despite the great efforts of educators for moral and social education, there are many gaps in the moral and social education programs of educational systems around the world (6). Raising a generation that adheres to social and moral norms and can live both as an effective member and compatible with other human beings and as a human being with excellence, to use social interactions for personal growth, is a matter that has a long history (7). Education means striving for desirable and valuable changes in individuals, and moral education is one of the concerns of parents and educators, and only with proper moral education can we expect a healthy and developed society (8). Moral education means a process effort to help people understand and learn moral values and act on them in real life (9). Also, social education is a process for understanding and recognizing oneself and situations, the realization of which ensures having appropriate behaviors in different social situations (10). Education and social development form the basis of one's life and cause the flourishing of one's intellectual development and communication skills in social life or living with others (11). Social education cultivates aspects of personality that are related to interpersonal relationships and the development of skills necessary for social life and lead to a greater understanding of social environments (12). In Iran, after the Islamic Revolution, great importance was given to moral and social education and many efforts were made to promote it, but these goals were not achieved. The behavior of the young generation indicates many problems in this field and the evidence of this claim is the expansion of crime, increase of addiction, spread of diseases such as AIDS, incorrect and immoral use of new means of communication such as Internet and equality of lawsuits in the country (3). In schools, students are taught skills such as the ability to fight injustice, accountability, mutual understanding, cooperation and participation, respect for cultures, awareness of international and environmental rights, peace and human rights, and respect for race and religion in an integrated and comprehensive manner (13).

Few and scattered researches have been done on the factors affecting moral and social education. For example, research results showed that living environment and education, the use of moral reasoning, supportive atmosphere, psychological, social and educational harms, creating and promoting cognition and moral virtues are effective on students' moral development (14). Another study showed that the purpose of the Qur'an in designing 
patterns is to introduce worthy patterns, flourish the talents of educators and coordinate social patterns, which requires knowledge of patterns, responsibility, imitation and a sense of aesthetics (15). In another study on the dimensions and components of moral education with a social approach, 11 components were identified in two dimensions of belief and behavior. Belief dimension includes respect for social values and norms, open-mindedness, cultivating altruism and dialogue, and behavior dimension including belonging to collective identity and preservation. It was to cultivate the spirit of freedom, peaceful coexistence, fulfillment of covenants, adherence to moral precepts, respect for the environment and social responsibility (16). In another study, factors of moral development in the family were introduced, including parenting styles, emotional reactions to abuse, grief, playing with siblings, and talking about moral issues (17). Also, the results of research on the adaptation of primary school textbooks with the components of social education document of the fundamental transformation of education showed that the conceptual axes in primary school textbooks paid the most attention to the axes of communication with others, knowledge, social ethics, communication skills and interaction with government institutions (18). In another study, the components of students' social education based on the document of fundamental transformation of education include religious democracy, responsibility, social participation, observance of laws and regulations, protection of values, unity, cooperation and brotherhood, communication skills, social relations, authority, commitment, liquidity. , Human dignity, justice, sacrifice and self-sacrifice, enjoining the good and forbidding the evil and social health were introduced (19). The results of another study showed that globalization and virtual social networks, in addition to the opportunities they provide for moral education, pose challenges in the field of moral education (20).

Studies show that Iranian society is experiencing a decline in moral behavior in social relations, which is not due to lack of awareness of moral principles. Because the evidence shows that individuals, while acknowledging the goodness of moral values, avoid adhering to it in social relations (21). Also, the need to coordinate with the rapid changes and transformations of societies and benefit from successful educational experiences, the need for fundamental change in the education system became more and more apparent, and this is one of the goals of the document of fundamental change in education. Therefore, the study of the factors affecting the moral and social education of students based on this document is necessary to help identify the effective factors and use them to improve moral and social education. In addition, although many efforts have been made in recent decades in the field of moral and social education, but there are many gaps in the moral and social education programs of schools and the study of student behavior shows the failure of these programs. As a result, this study was conducted to identify the factors affecting the moral and social education of students with emphasis on the document of fundamental reform in education. Therefore, the research questions are:

1. What are the main and secondary factors affecting the ethical and social education of students with emphasis on the document of fundamental transformation of education?

2. What is the conceptual model of the factors affecting the ethical and social education of students with emphasis on the document of fundamental change in education?

\section{Material \& Methods}

This study was applied in terms of purpose and content analysis in terms of quality implementation. The research community was documents and resources and education experts. The research sample was documents and resources related to moral and social education and 22 education experts who were selected according to the principle of theoretical saturation and after reviewing the inclusion criteria by purposive sampling. In this sampling method, the researchers identified the experts and selected them as a sample according to the purpose of the research and the inclusion criteria. These criteria include having sufficient information about the factors affecting the moral and social education of stu- 
dents and having at least two of the three characteristics: 1) Professorship in the field of education, 2) Having a book or article in the field of moral and social education and 3) Having experience in teaching the students. In this study, considerations such as participants' awareness of the purpose, importance and necessity of the research, informed consent, anonymity of interviews, confidentiality, confidentiality of personal information, etc. were considered for participants. Among the participants of the present study, 3 were faculty members with ph.d degrees (13.64\%), 11 were directors and teachers of education with specialized ph.d. (50\%) and 8 were general managers, deputies and education experts with ph.d degrees. And were masters $(36.36 \%)$. To ensure the validity of the research, the methods of review by participants, data alignment and review by non-participants were used. For this purpose, some of the interviewees were asked to review the analysis process or the obtained factors and express their opinion about them. Also, data alignment was used to further ensure validity. For this purpose, various sources were used, including data collection of theoretical foundations related to research variables and research conducted in this field, opinions of experts and experts and opinions of the director general, deputies and education experts to provide more accurate data on factors affecting moral and social education by emphasizing the document of fundamental transformation of education.

Table. 1: Results of content analysis from

\begin{tabular}{|c|c|c|c|c|c|}
\hline \multirow[t]{2}{*}{ Axial codes } & \multirow[t]{2}{*}{ Open codes } & \multicolumn{2}{|c|}{ Reference of codes } & \multirow[t]{2}{*}{ Frequency } & \multirow[t]{2}{*}{ Percentage } \\
\hline & & literature & Interview & & \\
\hline \multirow[t]{5}{*}{ Individual } & Physical and mental health & $14 \& 22$ & M1 \& M2 & 4 & 16 \\
\hline & Patternability & $14,22 \& 23$ & M3 \& M6 & 5 & 20 \\
\hline & Attention to spiritual issues & $14,24 \& 25$ & $\begin{array}{l}\text { M1, M3, M4, M6 } \\
\text { \& M9 }\end{array}$ & 8 & 32 \\
\hline & $\begin{array}{l}\text { Adherence to moral and so- } \\
\text { cial values }\end{array}$ & $16 \& 26$ & M11 \& M12 & 4 & 16 \\
\hline & $\begin{array}{c}\text { Practical experience of moral } \\
\text { and social behavior }\end{array}$ & $17 \& 25$ & M5 \& M7 & 4 & 16 \\
\hline \multicolumn{4}{|c|}{$\begin{array}{lc}\text { Total } \\
\end{array}$} & 25 & 100 \\
\hline
\end{tabular}

According to the results of table 1, in the individual factor, respectively, five sub-factors are attention to spiritual issues $(32 \%)$, patternability $(20 \%)$, physical and mental health $(16 \%)$, adherence to
The process of conducting the research was that after taking notes from documents and resources in the field of moral and social education, experts were interviewed in a semi-structured way. After coordination by telephone or in-person, the date and time of the interview were determined and the interviews were conducted at the specified time. Important and key points were noted during the interview and for this information not to be lost, the interviews were recorded for re-examination after the knowledge and consent of the interviewees.

To analyze the data, content analysis method was used with the help of MAXQDA software. This method is a technique that involves identifying the main and sub-concepts, categories and factors that are done in three stages of open, axial and selective coding.

\section{Results}

The results of content analysis showed the identification of 6 main categories or factors in the form of 35 indicators or sub-factors, of which 6 main categories or factors included individual factors, family, local community, school, media and information technologies and changes in the global community. The results of content analysis from the literature and interviews for the individual agent were reported in table 1. moral and social values (16\%) and practical experience of moral and social behavior $(16 \%)$ had the most role; thus, the role of the three factors of physical and mental health, adherence to moral and social values and practical experience of moral 
and social behavior was equal. The results of content analysis from literature and interviews for the family agent were reported in Table 2 .

Table 2: Results of content analysis from literature and interview for family agent

\begin{tabular}{|c|c|c|c|c|c|}
\hline \multirow[t]{2}{*}{ Axial codes } & \multirow[t]{2}{*}{ Open codes } & \multicolumn{2}{|c|}{ Reference of codes } & \multirow{2}{*}{$\begin{array}{c}\text { Fre- } \\
\text { quency }\end{array}$} & \multirow{2}{*}{$\begin{array}{l}\text { Percent- } \\
\text { age }\end{array}$} \\
\hline & & References & Interview & & \\
\hline \multirow[t]{8}{*}{ Family } & Positive self-concept & 17 & M2, M3 \& M9 & 4 & 7.41 \\
\hline & Disciplinary methods & $17,27 \& 28$ & M3, M5 \& M7 & 6 & 11.11 \\
\hline & Play with children & 17 & M3, M5 \& M7 & 4 & 7.41 \\
\hline & $\begin{array}{c}\text { Relationship of family members with } \\
\text { each other }\end{array}$ & $17,29,30 \& 31$ & M2, M4, M5, M6 \& M9 & 9 & 16.67 \\
\hline & Parent-child behavioral models & $\begin{array}{c}14,17,27,29,30,31 \\
\& 32\end{array}$ & M1, M3, M6, M8 \& M9 & 12 & 22.22 \\
\hline & Family history & $24,31,32,33 \& 34$ & M6 \& M18 & 7 & 12.96 \\
\hline & Communication with others & $15 \& 18$ & M13 \& M14 & 4 & 7.41 \\
\hline & Religious teachings & $14 \& 24$ & $\begin{array}{l}\text { M11, M13, M16, M17, } \\
\text { M18 \& M22 }\end{array}$ & 8 & 14.81 \\
\hline \multicolumn{4}{|c|}{ Total } & 54 & 100 \\
\hline
\end{tabular}

According to the results of table 2 , in the family factor, respectively, eight sub-factors of parentchild behavioral models $(22.22 \%)$, relationship between family members $(16.67 \%)$, religious teachings $(14.81 \%)$, family history $(96.96 \%) 12)$, disciplinary methods $(11.11 \%)$, positive self-concept
(7.41\%), playing with children $(7.41 \%)$ and communication with others $(7.41 \%)$ had the most role; In this way, the role of the three factors of positive self-concept, playing with children and communication with others was equal. The results of content analysis from literature and interviews for the local community agent were reported in table 3 .

Table 3. Results of content analysis from literature and interviews for the local community agent

\begin{tabular}{|c|c|c|c|c|c|}
\hline \multirow[t]{2}{*}{ Axial codes } & \multirow[t]{2}{*}{ Open codes } & \multicolumn{2}{|l|}{ Reference of codes } & \multirow{2}{*}{$\begin{array}{l}\text { Fre- } \\
\text { quency }\end{array}$} & \multirow{2}{*}{$\begin{array}{l}\text { Percent- } \\
\text { age }\end{array}$} \\
\hline & & References & Interview & & \\
\hline \multirow[t]{12}{*}{ Local society } & Optimal pattern & $15 \& 22$ & M6 \& M11 & 4 & 8.33 \\
\hline & Peers & $\begin{array}{l}14,17,27,35,36 \& \\
37\end{array}$ & M2 \& M12 & 8 & 16.67 \\
\hline & Strengthen social ties & --- & M1 \& M14 & 2 & 4.17 \\
\hline & $\begin{array}{l}\text { Interaction of public schools in pro- } \\
\text { moting ethics }\end{array}$ & 18 & M4 \& M10 & 3 & 6.25 \\
\hline & Link between ethics and social context & $16 \& 38$ & M11 \& M14 & 4 & 8.33 \\
\hline & $\begin{array}{l}\text { Avoid focusing solely on the social con- } \\
\text { cepts of ethics }\end{array}$ & 16 & M22 & 2 & 4.17 \\
\hline & $\begin{array}{l}\text { Belonging to and preserving collective } \\
\text { identity }\end{array}$ & 16 & M13 & 2 & 4.17 \\
\hline & $\begin{array}{l}\text { Social responsibility of community } \\
\text { members }\end{array}$ & $\begin{array}{l}15,16,39,40,41 \\
42,43 \& 44\end{array}$ & M12 \& M14 & 10 & 20.83 \\
\hline & $\begin{array}{l}\text { External strengthening of moral and so- } \\
\text { cial aspects }\end{array}$ & $16 \& 45$ & M14 \& M17 & 4 & 8.33 \\
\hline & Mental health of the community & --- & M1 \& M13 & 2 & 4.17 \\
\hline & Achieving social security & --- & M14 & 1 & 2.08 \\
\hline & Ethical and social incentives in society & $14,46 \& 47$ & M2, M5 \& M9 & 6 & 12.50 \\
\hline \multicolumn{4}{|l|}{ Total } & 48 & 100 \\
\hline
\end{tabular}

According to the results of table 3 , in the local community factor, respectively, twelve sub-factors of social responsibility of individuals in the community $(20.83 \%)$, peer group $(16.67 \%)$, moral and 
social incentives in the community $(12.50 \%)$, favorable model $(33 \%) / 8)$, the link between ethics and social context $(8.33 \%)$, external strengthening of moral and social aspects $(8.33 \%)$, interaction of government institutions in promoting ethics $(6.25 \%)$, strengthening social ties $(4.17 \%) 4)$, avoiding focusing only on social concepts of ethics (4.17\%), belonging to the collective identity and its preservation $(4.17 \%)$, mental health of the community $(4.17 \%)$ and achieving social security $(2.08 \%)$ had the most role; Thus, the role of the

Table 4 . Results of content analysis from

\begin{tabular}{|c|c|c|c|c|c|}
\hline \multirow[t]{2}{*}{ Axial codes } & \multirow[t]{2}{*}{ Open codes } & \multicolumn{2}{|c|}{ Reference of codes } & \multirow{2}{*}{$\begin{array}{l}\text { Axial } \\
\text { codes }\end{array}$} & \multirow{2}{*}{$\begin{array}{l}\text { Open } \\
\text { codes }\end{array}$} \\
\hline & & References & Interview & & \\
\hline \multirow[t]{5}{*}{ School } & Social and ethical Curriculum & 18 & M6 \& M11 & 3 & 12.50 \\
\hline & $\begin{array}{l}\text { Social and ethical knowledge of teachers } \\
\text { and staffs }\end{array}$ & $14 \& 41$ & $\begin{array}{l}\text { M2, M4, M5, M6 \& } \\
\text { M9 }\end{array}$ & 7 & 29.17 \\
\hline & Practical behavior of teachers and staffs & $3,28,33,36 \& 37$ & $\begin{array}{l}\text { M1, M2, M3, M6 \& } \\
\text { M18 }\end{array}$ & 10 & 41.67 \\
\hline & Ethical reasoning & $4 \& 48$ & --- & 2 & 8.33 \\
\hline & $\begin{array}{l}\text { Define ethics and community oriented } \\
\text { extracurricular activities }\end{array}$ & 3 & M10 & 2 & 8.33 \\
\hline \multicolumn{4}{|c|}{ ( } & 24 & 100 \\
\hline
\end{tabular}

According to the results of table 4, in the school factor, respectively, five sub-factors of practical behavior of teachers and staff $(41.67 \%)$, moral and social knowledge of teachers and staff $(29.17 \%)$, presentation of ethics-based and community-oriented curriculum $(12.50 \%)$, ethical reasoning $(8.33 \%)$ and the definition of ethics-oriented and community-oriented extracurricular activities three factors of the desired model, the link between ethics and the social context and the external strengthening of moral and social aspects and the role of the four factors of strengthening social ties, avoiding focusing only on social concepts of ethics, belonging to collective identity and maintaining it and mental health And the mentality of the society was equal. The results of content analysis from the literature and interviews for the school agent were reported in table 4.

\section{Table 5. Results of content analysis from literature and interviews for media and communication} technology agents

\begin{tabular}{|c|c|c|c|c|c|}
\hline \multirow[t]{2}{*}{ Axial codes } & \multirow[t]{2}{*}{ Open codes } & \multicolumn{2}{|c|}{ Reference of codes } & \multirow[t]{2}{*}{ Axial codes } & \multirow[t]{2}{*}{ Open codes } \\
\hline & & References & Interview & & \\
\hline \multirow[t]{3}{*}{$\begin{array}{l}\text { Media and } \\
\text { Information technologies }\end{array}$} & $\begin{array}{l}\text { IT and } \\
\text { Communication }\end{array}$ & $44,49 \& 50$ & M3, M5, M7 \& M8 & 7 & 41.18 \\
\hline & Social media & --- & M4, M5, M6 \& M9 & 4 & 23.53 \\
\hline & Usage media & $14 \& 51$ & $\begin{array}{l}\text { M1, M2, M3 \& } \\
\text { M22 }\end{array}$ & 6 & 35.29 \\
\hline \multicolumn{4}{|l|}{ Total } & 17 & 100 \\
\hline
\end{tabular}

According to the results of table 5, three sub-factors of information and communication technology $(41.18 \%)$, type of media use $(35.29 \%)$ and mass media $(23.53 \%)$ had the most important role in the media and information technology factor, respectively. The results of content analysis from the literature and interviews for the factor of local community change were reported in table 6 .
$(8.33 \%)$ had the most role; In this way, the role of the two factors of moral reasoning and the definition of extracurricular activities was equal to ethics and community. The results of content analysis from the literature and interviews for the media and communication technology agent were reported in table 5 .
According to the results of table 6, the two subfactors of globalization $(55.56 \%)$ and global changes $(44.44 \%)$ had the most important role in the change of local society, respectively. According to the results of content analysis, the conceptual model of factors affecting the moral and social 
education of students with emphasis on the document of fundamental change in education was reported in Fig.1.

Table 6. Content analysis results from literature and interview for the local community change

\begin{tabular}{|l|l|l|l|l|l|}
\hline \multirow{2}{*}{ Axial codes } & Open codes & \multicolumn{2}{l|}{ Reference of codes } & \multicolumn{2}{l|}{ Axial codes } \\
\cline { 3 - 6 } & References & Interview & 55.56 \\
\hline $\begin{array}{l}\text { Local } \\
\text { changes }\end{array}$ & Society & $4 \& 50$ & M2, M3 \& M10 & 5 & 44.44 \\
\cline { 2 - 6 } & $\begin{array}{l}\text { Globalization } \\
\text { opments }\end{array}$ & 3 & M1, M2 \& M10 & 4 & 100 \\
\hline Total & & & 9 & \\
\hline
\end{tabular}

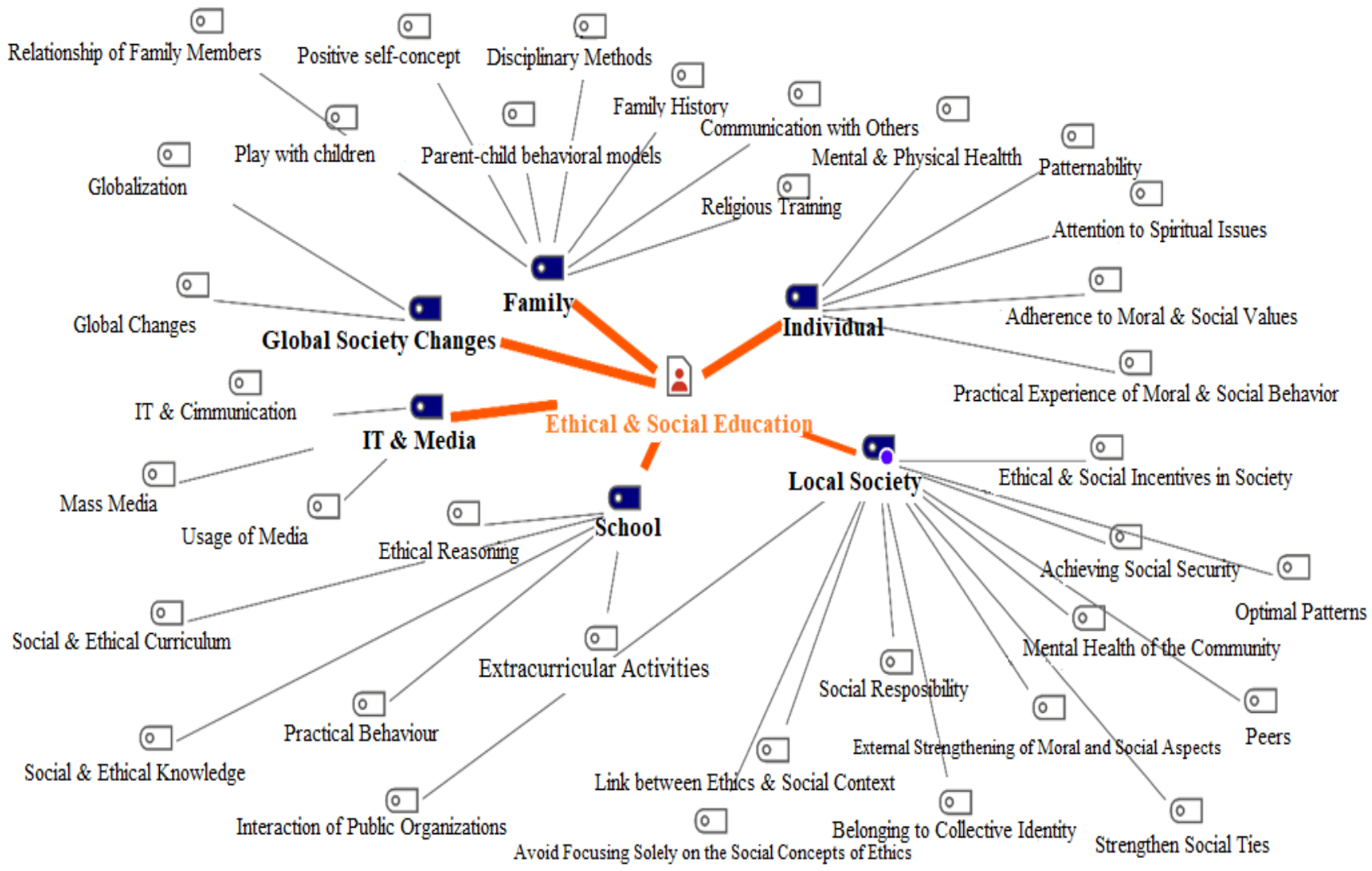

Fig 1. Conceptual model of factors affecting the moral and social education of students with emphasis on the document of fundamental change in education

\section{Discussion}

Considering the role of moral and social education in the growth and development of societies and the existence of few and scattered researches on the factors affecting them, this study was conducted to identify the factors affecting the moral and social education of students with emphasis on the document of fundamental change in education.

The results of the present study showed that the factors affecting the moral and social education of students with emphasis on the document of fundamental change in education included 6 main fac- 
tors and 35 sub-factors. Key factors included individual factors, family, local community, school, media and information technology, and global community change. Individual factor includes five sub-factors of physical and mental health, role modeling, attention to spiritual issues, adherence to moral and social values and practical experience of moral and social behavior, family factor includes eight sub-factors of positive self-concept, disciplinary methods, playing with children, relationship of family with each other, parent-child behavioral models, family history, relationships with others and religious teachings, local community factor including twelve sub-factors of the desired model, peer group, strengthening social ties, interaction of government institutions in promoting morality, the link between morality and social context avoid focusing only on the social concepts of ethics, belonging to the collective identity and maintaining it, social responsibility of individuals in society, external strengthening of moral and social aspects, mental health of society, achieving social security and moral and social incentives in society, school agent Includes five sub-factors: presenting ethics-oriented and community-oriented curriculum, moral and social knowledge of teachers and staff, practical behavior of teachers and staff, ethical reasoning and defining ethics-oriented and community-oriented extracurricular activities, media and information technology agent including three factors Information and communication technology, mass media and the type of media use and the factor of change in the global community included two sub-factors of globalization and global change and developments, which were in line with the results of previous research (11-17). In explaining and interpreting the results of the present study, it can be said that one of the important factors in moral and social development is the individual and his / her characteristics. Also, the individual or child is influenced by the family, and the family environment is like a university for the child in the educational environment. The family is crucial for the child, and when it comes to the family, the mind turns to the parents. The child learns from the mother the lesson of life, love and affection, and from the father the lesson of authority, discipline, and the quality of taking a stand on matters of social life. The family is the most important social institution that influences the personality of individuals and children inherit some of the characteristics and traits from their parents and learn others from the family and other environments and provide the family with the ground for the growth and emergence of talents. In addition, the school environment is always full of moral and social concepts and matters. There are many factors involved in the moral and social development of students in schools, with the teacher at the top of the pyramid. Because the student sets an example as a behavioral and moral model for the teacher. Sometimes the teacher with his inappropriate behavior causes the formation of incorrect behaviors in students and a significant part of students' learning and experiences is formed in the educational environment. If the learning environment is psychologically and educationally positive and students, teachers and school staff interact effectively, students will also grow socially and morally. The child also grows morally through interaction with peers and the development of cognitive capacities. Through these interactions, one learns solutions and creates ones that seem appropriate. Another important point is that the effects of television, video games, internet, advertising, etc. on children are very many, and these media, on the one hand, have positive educational and entertaining effects, and on the other hand, have negative effects on children. A review of various studies suggests that there is a direct correlation between violent behavior and viewing violent media. Such children are often aggressive, more likely to conflict with teachers and school staff, often engaging with peers, receiving lower grades, and lacking in moral and social development. Finally, globalization and virtual social networks, in addition to the opportunities they provide for moral and social education, can pose challenges. Virtual social networks are like a doubleedged sword that, if not managed and controlled, affects not only morality but also the religious teachings of individuals, and is a wake-up call for education in today's society. 


\section{Conclusion}

In general, the results of the present study showed that six factors: individual, family, local community, school, media and information technologies and changes in the global community were among the factors affecting the ethical and social education of students with emphasis on the document of fundamental change in education. The main factor and its sub-factors were the pattern of moral and social education. According to this model, education specialists and planners can design and implement programs to improve the moral and social education of students. As a result, policymakers and executors of upstream documents in education should be more aware of the implementation of the provisions of the document on the fundamental transformation of education in the field of moral and social education and consider its areas and continuously examine the extent of their realization and achievement.

\section{Ethical Consideration}

Ethical issues (such as plagiarism, conscious satisfaction, misleading, making and or forging data, publishing or sending to two places, redundancy and etc.) have been fully considered by the writers.

\section{Acknowledgement}

The authors would like to express their sincere thanks to the interviewees and the people who helped us in this research.

\section{References}

1. Woods O, Kong L (2020). The spatial subversions of global citizenship education: Negotiating imagined inclusions and everyday exclusions in international schools in China. Geoforum, 112: 139-147.

2. Vafai R, Fazlollahi Ghomshi S, Taleifard A (2017). The coverage of the six educational domains of fundamental reform document of education in primary school social studies textbooks. Journal of Applied Issues in Islamic Education, 2(2): 131-154. (In Persian).
3. Vojdani F, Imani M, Sadeghzadeh Ghamsari A (2014). How to change the current system of moral education in schools to reduce the gap between knowledge and action, from Allameh Tabatabai's viewpoints. Foundations of Education, 4(1): 111-130. (In Persian).

4. Heydarizadeh N, Esmaeeli Z, Farajillahi M, Safaee T (2018). Design and validation of moral education appropriate to characteristics elementary students in Iran emphasizing the document on the fundamental transformation of education. Journal of Researh in Education Systems, 12: 231-247. (In Persian).

5. Kianimoghadam AS, Bakhtiari M (2020). Socio-moral development of preschool children. Journal of Pizhubish dar Din va Salamat, 6(3): 1-6. (In Persian).

6. Nicholson CY, DeMoss M (2009). Teaching ethics and social responsibility: An evaluation of undergraduate business education at the discipline level. The Journal of Education for Business, 84(4): 213-218.

7. Boosliki H (2019). Factors contributing to moral development of children in parent-child relation from a moral psychological view. Quarterly Joumal of Moral Studies, 2(4): 113135. (In Persian).

8. Monteiro F, Leite C, Rocha C (2019). Ethical education as a pillar of the future role of higher education: Analyzing its presence in the curricula of engineering courses. Futures, 111: 168-180.

9. Megregian M, Low LK, Emeis C, DeVries R, Nieuwenhuijze M (2020). "I'm sure we talked about it": Midwives experiences of ethics education and ethical dilemmas, a qualitative study. Women and Birth, 33(6): 519-526.

10. Moody CT, Laugeson EA (2020). Social skills training in autism spectrum disorder across the lifespan. Psychiatric Clinics of Nonth America, 43(4): 687-699.

11. Gray PH, Edwards DM, Hughes IP, Pritchard M (2018). Social-emotional development in very preterm infants during early infancy. Early Human Development, 121: 44-48.

12. Jafari Harandi R, Najafi H (2019). Social and political education presented in high school textbooks. Journal of Curriculum Studies, 14(52): 159-184. (In Persian)

13. Butcher J (2017). Citizenship, global citizenship and volunteer tourism: A critical analysis. Tourism Recreation Research, 42(2): 156-172.

14. Amini Z, Hanifi F, Imani M (2020). Identifying the factors affecting the moral development of elementary school students in Tehran from the perspective of experts in order to provide an appropriate model. Quarterly Educational Development of Jundishapur, 11: 227-242. (In Persian).

15. Jannesari HA, VaeziSH (2019). The role of ethical models in social education from the perspective of the Holy Quran. Quran and Hadith Studies, 51(2): 75-96. (In Persian). 
16. Kaveshi Z, Mousapour N, Mohebbi A, Armand M (2018). Identification of the dimensions and components of moral education through a social approach and developing a conceptual model for elementary education. Journal of Applied Issues in Islamic Education, 3(2): 117-142. (In Persian).

17. Boosliki H (2018). A model for the factors and mechanisms of the influence of family and media in moral development with emphasis on the teachings of the Quran and Sunnah in the interpretation of Al-Mizan and Bahar AlAnwar. [PhD Thesis].Qom University of Islamic Education, Iran. (In Persian)

18. Habibi A, Hajmohseni M, Zahediaval N, Ebrahimidoost MA (2018). Content analysis of preschool books based on the components of the national identity fundamental reform document of education. $3^{\text {rd }}$ National Conference on New Approaches in Education and Research, Iran. (In Persian).

19. Zanghaneh A (2014). Assessing the components of social education of high school students based on the social dimensions of the fundamental reform document in education from the perspective of teachers in Aliabad Katoul. [MA Dissertation]. Allameh Tabatabaei University, Tehran/Iran. (In Persian).

20. Sahranavard B, Moghadamnia N, Mousavi F (2015). Globalization and education. National Conference on Training and Development of Human Resources, Iran. (In Persian)

21. Poursalim A, Arefi M, Fathi Vajargah K (2017). Designing a model for the curriculum of global citizenship education in elementary schools of Iran's educational system: A model based on grounded theory. Quarterly Journal of New Thoughts on Education, 13(3): 7-36.

22. Ganji H (2000). Mental health. Samt Publications, Tehran/Iran. (In Persian)

23. Anne DS, Sushma RK, Arvind KP, Pragna R, Sneha GK (2020). Cadaver as a first teacher: A module to leam the ethics and values of cadaveric dissection. Journal of Taibah University Medical Science, 15(2): 94-101.

24. Ebrahimpour H, Roshandel Arbatani T, Sokhandan E (2018). The role of spirituality in the workplace on the growth of ethical behavior of university employees. Iranian Joumal of Management in the Islamic University, 6(14): $177-$ 192. (In Persian)

25. Danaei M (2016). The relationship between social skills and theory of mind with moral development among fifth grade elementary school students in Ashkhaneh city. [MA Dissertation].University of Mazandaran, Iran. (In Persian)

26. Fatehi Ebrahimabad A, Shamsabadi R, Derakhshanfar T (2015). Belief, devotional and ethical education based on the fundamental reform document of education. The $2^{\text {nd }}$
International Conference on Psychology, Educational Sciences and Lifestyle, Mashhad/Iran. (In Persian)

27. Kaboli MR, Gharjalou D (2013). Stages of moral development in children. Monthy Book of the Month of Children and Adolescents, 186: 19-29. (In Persian)

28. Lepp B, Barkley JE, Karpinski AC (2014). The relationship between cell phone use, academic performance, anxiety, and Satisfaction with Life in college students. Computers in Human Behavior, 31: 343-350.

29. Paymannia B, Broumandnasab M (2013). The relationship between parenting styles and adolescents' moral development based on Kohlberg's moral development riddles. National Congress of Child and Adolescent Psychology, Iran.

30. Manouchehrinia S (2013). Explaining the fields of moral education in childhood based on the perspective of Islam. [MA Dissertation].University of Shahid Bahonar Kerman, Iran. (In Persian)

31. Khalajabadi Farahani F, Mehyar AH (2011). The role of family in premarital heterosexual relationships among female university students in Tehran. Journal of Family Research, 6(4): 449-468. (In Persian)

32. Kroger J (1995). The differentiation of "firm" and "developmental" foreclosure identity statuses: A longitudinal study. Journal of Adolescent Researh, 10(3): 317-337.

33. Shahassani Sh, Shamshiri B, Moradkhah V, Rasekh M (2017). The importance of moral education in students and its methods. $2^{\text {nd }}$ National Conference on Psychology and Counseling, Isfahan/ Iran. (In Persian)

34. Grych DK, Fincham J (1990). The growth of interpersonal underestanding: Developmental and clinical analyses. Academic Press. New York/USA.

35. Manavipour D (2012). Construction measures for the moral development scale of students. Journal of Modern Thoughts in Education, 7(4): 89-96. (In Persian)

36. Hanifi F, Karamali A, Zohrehei MA (2015). Identifying the effecting factors of moral and social development of girls' elementary school students in Tehran. International Conference on New Approaches in the Humanities, Iran. (In Persian).

37. DeBoo GM, Prins PJM (2007). Social incompetence in children with ADHD: possible moderators and mediators in social-skills training. Clinical Psychology Review, 27(1): 7897.

38. Norouziasl E (2018). Investigating the components of moral education in the fundamental reform document of education. $6^{\text {th }}$ National Conference on Sustainable Development in Educational Sciences and Psychology, Social and Cultural Studies, Tehran/Iran. (In Persian) 
39. Farid M (2017). Al-Hadis: Educational narrations from the school of AbleBayt (AS). Islamic Culture Publishing Office, Iran. (In Persian).

40. Pasha Gh, Goudarzian M (2013). The relationship of identity styles and moral development with responsibility in students. Social Psychology: New Finding in Psychology, 2(8): 87-99. (In Persian)

41. Karimi M, Rajaeipour S, Hoveyda R (2010). Investigating the relationship between dimensions of organizational atmosphere and ethical behavior among staff of University Isfahan and Isfahan Medical Sciences. Quarterly Journal of Educational Leadership \& Administration, 4(1): 83-102. (In Persian)

42. Whiting TB, Whiting JWM (1975). Children of six cultures: $A$ psychocultural analysis. Harvard University Press, Cambridge.

43. Cant MC (2000). Psychosocial predictors of children and self-care behaviors. American Diabest Association Publication, USA.

44. Stams GJ, Brugman D, Dekovic M, Van Rosmalen L, Vander Laan P, Gibbs JC (2006). The moral judgment of juvenile delinquents: a meta-analysis. Journal of Abnormal Cbild Psychology, 34(5): 697-713.

45. Ghasemi M, Sharifi MR, Iravani Sh, Sajjadi M (2017). Social approach to moral education in Islam through recon- ceptualization in components of Dewey, Durkheim, Habermas point of view. Journal of Philosophy \& History of Education, 1(1): 93-114. (In Persian)

46. Lickona T (1994). Raising good cbildren: From birth through the teenage years. Bantam Books, Toronto/Canada.

47. Vishal K, Elias M (2018). An ethical appraisal of livinganonymous kidney donation using Adam Smith's theory of moral sentiments. Health Policy, 122(11): 1212-1221.

48. Yaghoobi A, Abdolahi Moghadam M (2016).Investigating the relationship between moral reasoning and moral behavior in adolescents mediated by social cognition theory. Joumal of School Psychology, 5(2): 167-182. (In Persian)

49. Javadi Amoli AS (2012). Mafatih Al-Hayah. Boostan Ketab Publisher, Qom / Iran. (In Persian)

50. Mousavi P, Yousefizenouz R, Hasanpoor A (2015). Identifying organizational information security risks using fuzzy Delphi. Journal of Information Technology Management, 7(1): 163-184. (In Persian)

51. Keramati M, Emadian SO (2016).The relationship between moral development, SMS addiction and dropout rates amongst students. Quarterly Journal of Information and Communication Technology in Educational Sciences, 6(4):111-126. 